\title{
KONSEP ADVOKASI TERHADAP ANAK KORBAN PERDAGANGAN ANAK
}

\author{
Saiful Ansari \\ Pascasarjana IAIN Palangka Raya \\ email: saifulanshari7497@gmail.com
}

\begin{abstract}
Child victims of child trafficking in Indonesia need to take action that leads to forms of defense, assistance, protection, and support from various parties. Law number 21 of 2017 concerning the eradication of the criminal act of trafficking in persons in article 35 explains that during the process of investigation, prosecution, and examination at court proceedings, witnesses and/or victims have the right to be accompanied by an advocate and/or other companion needed. The purpose of this paper is to provide an advocacy concept for child victims of child trafficking, for the realization of legal protection. This research is normative legal research using a conceptual approach and a statutory approach. Meanwhile, the results of this study reveal that the concept of advocacy for child victims of child trafficking consists of legal consultation, legal assistance, and legal protection. Meanwhile, the rights of children who are victims of child trafficking that need to be given are reparation rights, compensation rights, restitution rights, and rehabilitation rights.
\end{abstract}

Keywords: Advocacy, Child Trafficking

Setiap tahunnya di dunia selalu mengalami peningkatan terkait pelanggaran hak asasi manusia terhadap anak, salah satunya perdagangan manusia. Perdagangan manusia adalah bentuk kejahatan yang sulit untuk dibasmi dan salah satu bentuk perbudakan modern yang melanggar hak asasi manusia (Prakoso, 2016). Meskipun, terdapat peraturan perundang-undangan yang mengakomodir tindak pidana perdagangan anak tersebut. Pada realitanya, anakanak merupakan kelompok yang banyak diminati untuk diperjualbelikan dengan tujuan yang beragam yakni: pembantu rumah tangga, prostitusi, hingga penjualan organ tubuh.

Perdagangan anak merupakan bentuk kejahatan yang melanggar harkat dan martabat manusia. Hal ini sangat disayangkan, sebab anak adalah generasi yang meneruskan cita-cita Bangsa. Maraknya kasus perdagangan anak di Indonesia, tentu menjadi permasalahan bersama terutama bagi aparat penegak hukum di Indonesia diantaranya: Hakim, Jaksa, Advokat dan Polisi. Seluruh unsur penegak hukum diharuskan untuk mencegah dan menindaklanjuti terkait 
permasalahan traficking yang sering menimpa anak sebagai korbannya. Salah satu unsur penegak hukum yang turut berperan dalam mengatasi permasalahan tersebut ialah advokat.

Profesi advokat sudah lumrah ditelinga masyarakat Indonesia. Kehadirannya sangatlah penting guna mewujudkan tegaknya supremasi hukum. Saat ini, praktisi advokat sudah banyak ditemukan dan mengalami perkembangan yang pesat (Ansari, 2019). Advokat berperan untuk melaksanakan advokasi, yakni kegiatan atau upaya yang dilakukan oleh seseorang maupun kelompok dengan tujuan memfasilitasi serta memperjuangkan hak-hak dan kewajiban klien berdasarkan ketentuan peraturan perundang-undangan yang berlaku (Kusnadi, 2012).

Tindak pidana perdagangan anak juga perlu pendampingan hukum dari advokat. Mengingat dalam hal ini anak merupakan korban dari tindak kejahatan perdagangan manusia yang nantinya akan berurusan di persidangan, maka peran dari advokat sangatlah dibutuhkan untuk mendampingi anak dalam berperkara di persidangan. Pendampingan hukum oleh advokat ialah kepada anak merupakan ketentuan yang di atur dalam UU. No. 21 Tahun 2007 Terkait Tindak Pidana Perdagangan Orang. Pada pasal 35 ditegaskan bahwa: "sepanjang proses penyidikan, penuntutan, serta pemeriksaan di persidangan, saksi serta/ataupun korban berhak untuk didampingi oleh advokat serta/ataupun pihak lain yang dibutuhkan".

Oleh sebab itu, penulis tertarik untuk mendiskusikan terkait hak-hak anak yang perlu diadvokasi dalam menghadapi korban perdagangan anak dan mengemukakan konsep advokasi terhadap anak korban perdagangan anak guna melindungi hak-hak anak tersebut.

\section{METODE}

Berangkat dari topik yang dibahas dalam tulisan ini, maka jenis penelitian ini ialah penelitian hukum normatif melalui pendekatan konseptual serta perundangundangan. Dengan demikian, pembahasan ini juga melibatkan bahan hukum primer dan sekunder, yakni peraturan perundang-undangan yang berkaitan terhadap objek penelitian serta dokumen lainnya seperti buku, artikel dan lainnya. 


\section{PEMBAHASAN}

Istilah advokasi berasal dari bahasa inggris, yakni advocacy. Advokasi ialah tindakan yang mengarah pada bentuk pembelaan, dukungan, maupun rekomendasi (dukungan aktif). Orang yang ahli dan terampil dibidang advokasi, maka disebut dengan istilah advokat. Terdapat dua macam advokasi, yaitu advokasi litigasi dan advokasi non-litigasi. Advokasi litigasi merupakan seluruh bentuk advokasi yang ada didalam persidangan di pengadilan. Sedangkan advokasi non-litigasi merupakan kebalikan dari advokasi litigasi, yakni seluruh bentuk advokasi di luar di pengadilan (Tarantang, 2018).

Pihak yang melakukan advokasi tidak hanya pemerintah maupun aparat penegak hukum. Akan tetapi, lembaga sosial maupun masyarakat bisa ikut serta dalam melakukan advokasi. Pada pasal 72 ayat 1 UU. No. 23 Tahun 2002 Tentang Perlindungan Anak menegaskan jika seluruh lapisan masyarakat berhak untuk mendapatkan peluang seluas-luasnya serta berfungsi dalam memberikan perlindungan terhadap anak. Perbuatan pidana merupakan tindakan yang dilarang oleh hukum dan disertai ancaman (sanksi) berupa pidana tertentu. (Moeljatno, 2008). Adapun perbuatan pidana ialah bentuk pelanggaran terhadap norma-norma pada tiga bagian hukum, yakni hukum perdata, hukum ketatanegaraan serta hukum tata pemerintah (Prodjodikoro, 2003).

Jauh sebelum lahirnya peraturan perundang-undangan terkait pemberantasan tindak pidana perdagangan manusia, maksud dari perdagangan manusia merupakan perekrutan, pengiriman, pemindahan, penampungan atau penerimaan seseorang dengan mengancam atau menggunakan kekerasan dan bentuk lain dari pemaksaan, penculikan, penipuan, kebohongan atau untuk tujuan eksploitasi (Farhana, 2010).

Oleh karena itu, seseorang yang berbuat tindak pidana maka mempunyai keharusan untuk mempertangggung jawabkan kejahatannya tersebut di muka hukum. Pertanggung jawaban pidana adalah pertanggung jawaban seseorang terhadap kejahatan yang dilakukannya. Adanya pertanggung jawaban pidana tersebut dikarenakan terdapat suatu tindak pidana yang dilakukan. Hakikatnya, 
pertanggung jawaban tersebut ialah sebagai bentuk reaksi terkait pelanggaran atas kesepakatan suatu perbuatan tertentu (Huda, 2006).

Landasan hukum advokasi terkait korban tindak pidana perdagangan anak terdiri dari: (1) UU. No. 39 Tahun 1999 Terkait Hak Asasi Manusia; (2) UU. No. 21 Tahun 2007 Terkait Pemberantasan Tindak Pidana Perdagangan Orang; (3) UU. No. 35 Tahun 2014 Tentang Perubahan Atas UU. No. 23 Tahun 2002 Terkait Perlindungan Anak; (4) UU. No. 4 Tahun 1979 Terkait Kesejahteraan Anak; (5) UU. No. 11 Tahun 2012 Terkait Sistem Peradilan Pidana Anak; serta (6) UU. No. 13 Tahun 2006 Terkait Perlindungan Saksi dan Korban.

Berdasarkan peraturan perundang-undangan tersebut, dapatlah untuk dijadikan sebagai dasar hukum dalam melakukan kegiatan advokasi terhadap anak korban perdagangan anak. Selain itu, adanya peraturan tersebut diharapkan mampu untuk memperkuat status para pendamping ketika memberikan layanan advokasi kepada anak korban perdagangan anak. Penting juga adanya kerja sama seluruh lapisan masyarakat dalam mencegah dan melindungi anak dari korban perdagangan anak. Dalam menerapkan peraturan-peraturan tersebut perlu adanya respon dan aksi dari seluruh lapisan masyarakat. Menurut Sabian Utsman: "Pada dasarnya manusia sebagai makhluk yang bukan hanya merespons namun juga beraksi dan dengan aksinya tersebut, ... keberadaan peraturan perundangundangan atau hukumlah yang menjadi alat kontrolnya...”(Utsman, 2016).

Selain itu, memberikan perlindungan terhadap anak dalam agama Islam adalah suatu hal yang wajib untuk dilaksanakan oleh orang tua. Kewajiban tersebut termaktub pada suatu ayat di dalam al-Qur'an sebagai berikut:

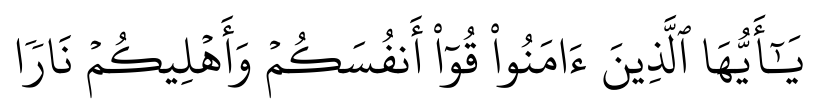

Artinya: "Hai orang-orang yang beriman, peliharalah dirimu dan keluargamu dari api neraka”.

Makna dari kandungan ayat di atas ialah bahwa manusia harus bisa melindungi diri pribadi beserta keluarganya dari perilaku yang pada akhirnya dapat memudharatkan diri dan hidupnya. Namun, kewajiban tersebut tidak hanya 
dipikul oleh orang tua semata. Peran aktif dari pemerintah juga diperlukan dalam melindungi anak tersebut (Chusniatun, 2016).

\section{A. Hak Anak Korban Perdagangan Anak}

1. Repair Rights

Reparasi merupakan upaya untuk memulihkan keadaan anak sebagai korban dari perdagangan anak agar kembali kepada keadaan semula. Reparasi terdiri dari berbagai aspek, yakni pemulihan keadaa fisik, psikis, harta benda atau status sosial korban yang dirampas. Terkait perdagangan anak, cenderung menderita dalam hal mental maupun kejiwaan dari anak tersebut. Anak akan trauma akibat dari tindak pidana pelanggaran hak asasi manusia yang menimpanya. Apabila tidak ditanggapi secara tepat dan cepat, dikhawatirkan dapat menimbulkan problem yang berkepanjangan serta akan merusak psikologisnya (Susanti, 2013).

2. Compensation Rights

Kompensasi merupakan ganti rugi yang diberikan oleh negara disebabkan pelaku tindak pidana perdagangan anak tersebut tidak memiliki kemampuan untuk membayar ganti rugi secara penuh sebagaimana yang sudah menjadi tanggung jawabnya.

3. Restitution Rights

Adapun restitusi ialah suatu bentuk ganti rugi yang diberikan terhadap korban atau keluarganya oleh si pelaku maupun pihak ketiga. Ganti rugi tersebut berupa pengembalian harta milik, pembayaran ganti kerugian untuk kehilangan atau penderitaan, atau penggantian biaya untuk tindakan tertentu. Anak korban perdagangan anak berhak memperoleh resititusi atau ganti rugi akibat tindak pidana perdagangan orang. Sebagaimana yang terdapat dalam Pasal 48 ayat (1) dijelaskan juga bahwa: "Setiap korban tindak pidana perdagangan orang atau ahli warisnya berhak memperoleh restitusi". Kemudian ayat berikutnya, "Restitusi sebagaimana dimaksud pada ayat (1) berupa ganti kerugian atas: (a) Kehilangan kekayaan atau penghasilan; (b) Penderitaan; (c) Biaya untuk tindakan 


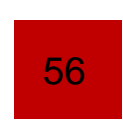

perawatan medis dan/atau psikologis; (d) dan/atau Kerugian lain yang diderita korban sebagai akibat perdagangan orang”.

4. Rehabilitation Rights

Rehabilitasi berasal dari kata re yaitu kembali dan habilitasi yang bermakna kemampuan. Dengan demikian, secara umum makna dari rehabilitasi tersebut ialah sebuah tahapan untuk membantu sesuatu hal agar dapat kembali seperti dulu, atau terdapat pengganti yang serupa seperti sebelumnya. Anak korban perdagangan anak berhak mendapatkan rehabilitasi sebagaimana yang tertuang dalam UU. No. 21 Tahun 2007 Tentang Tindak Perdagangan Orang pada pasal Pasal 51 ayat 1, "korban berhak memperoleh rehabilitasi kesehatan, rehabilitasi sosial, pemulangan, dan reintegrasi sosial dari pemerintah apabila yang bersangkutan menderita fisik maupun psikis yang diakibatkan dari tindak pidana perdagangan orang". Proses rehabilitasi tersebut bisa diajukan oleh berbagai pihak, seperti keluarga korban, rekan korban, pihak kepolisian, relawan, maupun pekerja sosial. Rehabilitasi tersebut bisa diupayakan dalam empat macam, yakni sebagai berikut: (Andenny, 2018)

a. Rehabilitasi ekonomi

Rehabilitasi ekonomi penting untuk dilakukan, mengingat salah satu faktor terjadinya perdagangan anak dikarenakan masalah finansial. Oleh sebab itu, perlunya pihak yang melakukan advokasi untuk memberikan rehabilitasi ekonomi kepada korban dalam hal ini ialah anak korban perdagangan anak atau orang tua korban sebagai modal usaha. Pelaksanaan rehabilitasi ekonomi ini pun juga bisa bekerja sama dengan beberapa instansi pemerintahan setempat.

b. Rehabilitasi sosial

Maksud dari rehabilitasi sosial ialah sebuah proses yang ditujukan kepada seseorang yang bukan hanya mengalami gangguan fungsi fisik dan mental belaka. Namun, juga diberikan kepada orang yang mengalami gangguan fungsi pada keadaan dan kondisi sosial dalam pergaulan di lingkungan masyarakat. Harapan dari rehabilitasi 


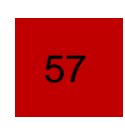

sosial ini ialah agar anak korban perdagangan anak dapat kembali atau mampu bergaul di masyarakat begitu pula sebaliknya, masyarakat juga siap sedia untuk menerima apapun kondisi anak tersebut. Untuk memperbaiki kesehatan psikis anak maka membutuhkan seorang konseling yang ahli dengan harapan sanggup untuk memberikan problem solving kepada korban. Dengan demikian, anak memperoleh pelayanan serta pendampingan guna mencetak ulang kehidupannya serta bersedia untuk menyatu dengan masyarakat secara luas.

c. Rehabilitasi pendidikan

Rehabilitasi pendidikan adalah bentuk pemulihan terhadap anak korban perdagangan agar kembali ke dunia pendidikan. Pihak advokasi diharapkan mampu untuk memberikan energi dan semangat guna mendorong korban agar kembali berminat melanjutkan pendidikannya. Adapun tujuan dari adanya rehabilitasi pendidikan ini tiada lain agar korban dapat terpenuhi haknya untuk mendapatkan pendidikan yang baik dan layak sebagaimana manusia lainnya.

Keempat macam hak-hak anak korban perdagangan anak tersebut bisa dilberikan layanan advokasi oleh siapa saja, baik itu unsur pemerintahan, praktisi penegak hukum maupun lapisan masyarakat. Pemberian layanan advokasi ini harus dilaksanakan hingga korban pulih dan mendapatkan hak-haknya sebagaimana yang telah diamanatkan peraturan perundang-undangan yang berlaku.

\section{B. Konsep Advokasi Terhadap Anak Korban Perdagangan Anak}

1. Pemberian Bantuan Hukum

Bantuan hukum merupakan suatu pemberian bantuan dalam bentuk hukum, dengan tujuan untuk memperlancar penyelesaian perkara. Ringkasnya, bantuan hukum merupakan seluruh kegiatan yang dilakukan oleh seorang pemberi bantuan hukum agar dapat menyelesaikan permasalahan hukum, baik dibidang pidana, perdata atau terkait administrasi negara. Pemberian bantuan hukum bisa dilakukan baik di dalam ruang pengadilan maupun di luar ruang pengadilan (Primts, 2002). 
Setiap anak yang bermasalah dengan hukum berhak untuk mendapatkan bantuan hukum tersebut. Hal ini tertera jelas dalam UU. No. 23 Tahun 2002 Terkait Perlindungan Anak yakni dalam pasal 18: "bahwa setiap anak yang menjadi korban atau pelaku tindak pidana mempunyai hak untuk mendapatkan bantuan hukum dan bantuan lainnya”.

Terkait bantuan hukum, sudah barang tentu akan melibatkan peran advokat dalam memberikan bantuan hukum kepada anak-anak yang berstatus sebagai korban tindak pidana perdagangan anak. Anak sebagai korban sangatlah awam untuk menyelesaikan kasus hukum tersebut. Terlebih dalam hal mendapatkan keadilan serta mempertahankan hak dan kepentingannya terhadap tindak pidana perdagangan anak tersebut. Untuk mengatasi hal tersebut, maka anak selaku korban perdagangan anak perlu diberikan bantuan hukum sejak awal pemeriksaan sampai diputuskannya hasil persidangan.

2. Layanan Konsultasi Hukum

Konsultasi hukum ialah suatu hubungan privasi antara konsultan klien (Hutagalung, 2012). Langkah pertama dalam memberikan layanan advokasi terhadap anak dapat menggunakan konsultasi hukum. Tujuan dari konsultasi hukum tersebut untuk memberikan pemahaman terkait perkara yang sedang dihadapi kepada klien atau korban. Konsultasi tersebut juga merupakan bagian dalam proses advokasi tindak pidana perdagangan anak yaitu berguna untuk membentuk pemahaman kepada anak ataupun keluarga korban terhadap persoalan yang dihadapi.

3. Identifikasi dan Analisis Kasus

Langkah selanjutnya yang dilakukan advokat di dalam proses advokasi terkait tindak pidana perdagangan anak ialah melakukan identifikasi persoalan atau kasus hukum yang hendak ditangani. Logikanya, semakin dini diketahui seluruh aspek kasus hukum yang menjadi obyek advokasi, maka semakin fokus dan akurat advis dan langkah hukum yang diambil. Dengan demikian, tahap identifikasi suatu kasus merupakan hal yang sangat penting dalam proses advokasi. 
Proses identifikasi yang akurat dan obyektif akan menghasilkan langkah dan strategi yang tepat dalam proses pemberian advokasi terhadap tindak pidana perdagangan anak. Terdapat manfaat dari tahap identifikasi kasus tersebut, yakni jika kasus tersebut adalah kasus hukum, maka aspek hukum apakah yang perlu diprioritaskan dalam advokasi hukumnya. Kemudian, jika kasus tersebut di luar bidang keahliannya perlukah meminta bantuan tenaga yang lebih ahli ataukah tidak sebaiknya kasus tersebut disarankan untuk ditangani oleh pihak yang lebih berkompeten, dan seterusnya.

Selanjutnya langkah yang mesti ditempuh pasca identifikasi adalah fase analisis kasus (case analysis). Tahap analisis kasus ini dilakukan guna mengetahui secara obyektif duduk persoalan atau fakta empiris dari suatu kasus dengan cara mengumpulkan informasi dan berbagai alat bukti yang berkaitan dengan kasus tersebut. Kemudian setelah itu dilakukan pula proses inventarisasi peraturan hukum maupun jurisprudensi yang berhubungan dengan kasus yang perlu diadvokasi tersebut. Bahkan perburuan informasi melalui literatur dan studi kepustakaan adalah sesuatu yang niscaya di dalam menganalis suatu kasus, karena ada kemungkinan kasus yang tengah dihadapi ternyata pernah terjadi atau setidaknya mirip dengan kasus di tempat lain. Seterusnya jika dirasa perlu, konsultasi dengan kaum intelektual hukum yang ahli di bidangnya perlu dilakukan untuk memperoleh kejelasan suatu kasus.

Berdasarkan serangkaian investigasi fakta dan norma hukum tersebut, maka kasus tersebut setidaknya telah diketemukan jawabannya secara hipotetis atau secara apriori, yakni tentang kedudukan klien, posisinya kuat (pihak yang benar) ataukah justru lemah (pihak yang salah). Selain itu, alat bukti apakah yang mesti dihadirkan untuk memperkuat posisi klien. Di samping itu, strategi apakah yang perlu ditempuh di dalam proses advokasi tersebut. Kemudian, prediksi mengenai probabilitas berhasil tidaknya advokasi hukum itu, dan seterusnya. 


\section{Memberikan Legal Opinion}

Pendapat hukum (legal opinion) biasanya digunakan untuk menjawab pertanyaan-pertanyaan klien tentang suatu permasalahan hukum tertentu. Pendapat hukum ini memang dimaksudkan untuk memberikan keterangan kepada klien yang ingin mengetahui segala hal yang berkenaan dengan permasalahan yang dihadapinya, maka isinya juga harus dapat memenuhi harapan si klien tersebut. Berdasarkan pernyataan di atas dapat ditarik kesimpulan bahwa fungsi dari pendapat hukum adalah untuk memberikan pendapat hukum atas suatu persoalan hukum agar didapat suatu keputusan atau tindakan yang tepat atas persoalan hukum tersebut. Dengan demikian, maka diperlukan kemampuan bagi orang hukum untuk memberikan pendapat hukum miliknya terhadap suatu permasalahan.

Pada dasarnya pendapat hukum merupakan bagian dari legal memoranda bersama dengan nasehat hukum (legal advice) dan pemecahan masalah hukum (problem solving). Adapun dalam penyusunan legal opinion terdapat lima aturan dasar (five golden rules) yang harus diikuti, yang terdiri dari: “(1) Issues atau pokok permasalahan; (2) facts atau fakta-fakta; (3) rules atau aturan hukum yang dapat atau mungkin dapat diterapkan dalam kasus tersebut; (4) application atau penerapan hukum; dan (5) conclusion atau kesimpulan”. (Benuf, 2020)

5. Pendampingan Hukum

Anak yang dihadapkan dengan tindak pidana perdagangan anak mempunyai hak untuk meminta pendampingan hukum kepada advokat atau pendamping lainnya. UU. No. 21 Tahun 2007 Tentang Tindak Pidana Perdagangan Orang dalam pasal 35 yang menyatakan bahwa, "selama proses penyidikan, penuntutan, dan pemeriksaan di sidang pengadilan, saksi dan/atau korban berhak didampingi oleh advokat dan/atau pendamping lainnya yang dibutuhkan”. Adapun maksud dari pendamping lainnya dalam pasal tersebut ialah psikolog, psikiater, ahli kesehatan, rohaniawan, dan anggota keluarga. Selanjutnya, pada pasal 39 ayat 2 menegaskan: "dalam hal pemeriksaan sebagaimana dimaksud pada ayat 1 
terkait saksi dan/atau korban anak wajib untuk didampingi oleh orang tua, wali, orang tua asuh, advokat, atau pendamping lainnya"

6. Perlindungan Hukum

Melindungi anak termasuk melindungi manusia seutuhnya. Bersikap acuh dalam melindungi anak mengakibatkan beragam problematika sosial yang dapat mengganggu tegaknya hukum, ketertiban, keamanan, serta pembangunan nasional (Salam, 2005). Terkait hak asasi terhadap anak merupakan kewajiban yang harus dilindungi dan diberikan dari semua orang kepada anak. Sebagaimana yang tertuang pada UU. No. 35 Tahun 2014 dalam Perubahan atas UU. No. 23 Tahun 2002 Tentang Perlindungan Anak pada pasal 1 ayat (12) bahwa, "hak anak adalah bagian dari hak asasi manusia yang wajib dijamin, dilindungi, dan dipenuhi oleh orang tua, keluarga, masyarakat, negara, pemerintah, dan pemerintah daerah".

Upaya hukum dalam memberikan perlindungan terhadap anak korban tindak pidana perdagangan manusia terdiri dari tiga tahapan, yakni tahapan perlindungan hukum ketika terjadinya tindak pidana, tahapan persidangan pelaku tindak pidana serta tahapan ketika putusan dibacakan di pengadilan. Agar lebih jelasnya, berikut uraian dari ketiga tahapan tersebut: (Fadilla, 2016)

a. Tahapan perlindungan hukum ketika terjadinya tindak pidana perdagangan manusia meliputi ancaman pemidanaan bagi siapa saja yang mengetahui dan sengaja membiarkan anak-anak yang tereksploitasi secara ekonomi dan/atau seksual, anak yang diperdagangkan.

b. Tahapan persidangan pelaku tindak pidana perdagangan manusia yang meliputi:

1) Penyidikan, penuntutan, serta pemeriksaan di ruang persidangan terhadap saksi dan/atau korban anak, maka dilakukan dengan memperhatikan kepentingan yang terbaik bagi anak dengan tidak menggunakan toga maupun pakaian dinas 
2) Persidangan tindak pidana perdagangan manusia dalam hal pemeriksaan terhadap saksi dan/atau korban anak, maka dilakukan dengan persidangan tertutup

3) Pemeriksaan saksi dan/atau korban anak wajib didampingi orang tua, wali, orang tua asuh, advokat, atau pendamping lainnya

4) Pemeriksaan terhadap saksi dan/atau korban anak, dilakukan atas persetujuan hakim dan dapat pula dilakukan di luar ruang persidangan dengan menggunakan alat perekam yang dilakukan di depan pejabat yang berwenang.

c. Tahapan ketika putusan dibacakan di pengadilan yaitu pemberian hak untuk mengajukan ke pengadilan berupa hak restitusi yang menjadi tanggung jawab pelaku kejahatan.

\section{KESIMPULAN}

Perdagangan anak merupakan tindakan pidana yang sangat membahayakan anak, baik mental, psikis dan bahkan tumbuh kembang anak. Salah satu upaya untuk memulihkan keadaan anak akibat korban perdagangan anak ialah dengan konsep advokasi yang tepat, efektif, dan profesional. Hak anak korban perdagangan anak yang perlu untuk diberikan advokasi, yakni: hak reparasi, hak kompensasi, hak restitusi dan hak rehabilitasi. Sedangkan konsep advokasi terhadap anak korban perdagangan anak terdiri dari: pemberian bantuan hukum, layanan konsultasi hukum, identifikasi dan analisis kasus, memberikan legal opinion, pendampingan hukum serta memberikan perlindungan hukum. 


\section{DAFTAR PUSTAKA}

Ali, M. (2011). Dasar-Dasar Hukum Pidana. Sinar Grafika.

Andenny, A. (2018). Perlindungan Hukum Terhadap Anak Korban Perdagangan (Human Trafficking) (Studi Kasus Di Wilayah Surakarta), Skripsi, Fakultas Hukum, Universitas Muhammadiyah Surakarta.

Ansari, S. (2019). Kecenderungan Penggunaan Jasa Advokat dalam Berperkara di Pengadilan Agama Kota Palangka Raya.

Chusniatun, (2016). "Perlindungan Anak dalam Perspektif UU Negara RI dan Islam". Suhuf, Vol. 28, No. 1, Mei, 58.

Ery Agus Priyono dan Kornelius Benuf, (2020). “Kedudukan Legal Opinion Sebagai Sumber Hukum”. Jurnal Suara Hukum, Vol. 2, No. 1, Maret, 63.

Fadilla, N. (2016). "Upaya Perlindungan Hukum Terhadap Anak Sebagai Korban Tindak Pidana Perdagangan Orang". Jurnal Hukum dan Peradilan, Vol. 5, No. 2, Juli. 191-192.

Farhana. (2010). Aspek Hukum Perdagangan Orang di Indonesia. Sinargrafika, Huda, C. (2006). Dari Tiada Pidana Tanpa Kesalahan Menuju Kepada Tiada Pertanggungjawaban Pidana Tanpa Kesalahan. Kencana.

Hutagalung, S. M. (2012). Praktik Peradilan Perdata Dan Alternatif Penyelesaian Sengketa. Sinar Grafikan.

Kusnadi, D. (2012). Bantuan Hukum Dalam Islam: Profesi Kepengacaraan Dalam Islam Dan Praktinya. Pustaka Setia.

Moeljatno. (2008). Asas-Asas Hukum Pidana. Rineka Cipta.

Prakoso, A. (2016). Hukum Perlindungan Anak. Laksbang Group.

Primts, D. (2002). Hukum Acara Pidana Dalam Praktek. Djambatan.

Prodjodikoro, W. (2003). Tindak-Tindak Pidana Tertentu di Indonesia. Rafika Aditama.

Salam, M. F. (2005). Hukum Acara Peradilan Anak di Indonesia, Mandar Maju.

Suprihatini, A. (2009). Perlindungan Terhadap Anak. Cempaka Putih. 
Susanti, A. (2013). Tinjauan Fikih Siyasah Dan Undang-Undang Nomor 23 Tahun 2002 Terhadap Advokasi Anak Yang Diperkosa Studi Kasus di LSM Dinar, Skripsi, Fakultas Syari'ah, Universitas Islam Negeri Sunan Ampel.

Tarantang, J. (2018). Advokat Mulia (Paradigma Hukum Profetik Dalam Penyelesaian Sengketa Hukum Keluarga Islam). K-Media.

Utsman, S. (2008). Menuju Penegakan Hukum Responsif. Pustaka Pelajar.

Utsman, S. (2016). Dasar-Dasar Sosiologi Hukum: Makna Dialog Antara Hukum Dan Masyarakat. Pustaka Pelajar. 